\title{
KONSEP KEPEMILIKAN DALAM ISLAM
}

\author{
Miftahul Jannah \\ Universitas Islam Negeri Alauddin Makassar \\ mfthuljnnh20@gmail.com
}

\begin{abstract}
This article explains the concept of ownership in Islam. Ownership in Islamic law is a legal provision and a person's power over what he has. In principle, Islam does not hinder the form and type of one's efforts to get wealth, nor does it hinder one's efforts to gain ownership. Given the importance of inheritance in economic construction, this article only explains the meaning of ownership universally and from an Islamic point of view, the types and effects of ownership in Islam on Islamic economic growth. After that, it ends with a conclusion like closing this article. Islamic thought on ownership is different from capitalism and socialism. For capitalist thought, property does not belong to the individual nor is it the common property of socialism. On the other hand, for Islamic thought, property belongs to Allah, because this matter is in the Qur'an and Sunnah. The concept of ownership in Islam comes from the point of view of humans who have the will to own individual property, but also require the participation of other parties in their social life.
\end{abstract}

Keywords: concept, ownership, property, Islam

\begin{abstract}
ABSTRAK
Artikel ini menerangkan tentang konsep kepemilikan dalam Islam. Kepemilikan dalam hukum Islam merupakan ketentuan hukum serta kekuasaan seseorang atas apa yang dimilikinya. Pada prinsipnya, Islam tidak menghalangi wujud serta tipe usaha seorang buat mendapatkan kekayaan, dan tidak pula menghalangi usaha seorang untuk mendapatkan kepemilikan. Mengingat berartinya peninggalan dalam konstruksi ekonomi, dalam artikel ini cuma menerangkan makna kepemilikan secara universal serta dari sudut pandang Islam, tipe serta pengaruh kepemilikan dalam Islam terhadap pertumbuhan ekonomi Islam. Setelah itu diakhiri dengan kesimpulan semacam penutup artikel ini. Pemikiran Islam terhadap kepemilikan berbeda dengan kapitalisme serta sosialisme. Bagi pemikiran kapitalisme, harta tidaklah kepunyaan individu serta bukan pula kepunyaan bersama bagi sosialisme. Sebaliknya bagi pemikiran Islam harta merupakan kepunyaan Allah, sebab perihal tersebut ada dalam Al- Quran serta AsSunnah. Konsep kepemilikan dalam Islam berasal dari sudut pandang manusia yang mempunyai kemauan buat memiliki harta individu, namun pula memerlukan partisipasi pihak lain dalam kehidupan sosialnya.
\end{abstract}

Kata kunci: konsep, kepemilikan, harta, Islam 


\section{PENDAHULUAN}

Salah satu wujud aktivitas yang terpaut dengan permasalahan ekonomi merupakan kepemilikan. Islam senantiasa membagikan ruang serta peluang untuk mengakses seluruh sumber kekayaan yang Ia miliki di bumi ini, dalam rangka memenuhihi seluruh kebutuhan hidup, memerangi kemiskinan serta menggapai kemakmuran dalam seluruh aspek kehidupan manusia.

Kepemilikan dalam hukum Islam merupakan ketentuan hukum serta kekuasaan buat berperan atas apa yang dimilikinya. Pada prinsipnya, Islam tidak menghalangi wujud serta tipe usaha seorang buat mendapatkan kekayaan, pula tidak lebih menghalangi sepanjang mana usaha seorang bisa dicapai.

Perihal itu bergantung pada tiap- tiap dari keahlian serta keahlian yang dipunyai seorang asalkan berusaha secara adil serta halal. Maksudnya, perihal tersebut legal bagi undang- undang serta tidak berisiko untuk dirinya ataupun orang lain.

Berikutnya, tiap orang pula diwajibkan memakai sebagian dari haknya untuk kepentingan kelompok warga, dan kepentingan negeri. Islam mengakui terdapatnya kepemilikan individu, publik serta negeri serta memakainya selaku dasar buat konstruksi ekonomi. Tetapi, kepemilikan yang sebetulnya terdapat di tangan Allah dan manusia cuma bisa memakainya dalam wujud keyakinan.

Mengingat berartinya peninggalan dalam konstruksi ekonomi, dalam artikel ini cuma menerangkan makna kepemilikan secara universal serta dari sudut pandang Islam, tipe serta pengaruh kepemilikan dalam Islam terhadap pertumbuhan ekonomi Islam. Setelah itu diakhiri dengan kesimpulan semacam penutup artikel ini.

\section{PEMBAHASAN}

\section{A. Definisi Kepemilikan}

Dalam bahasa Arab, kepemilikan ataupun milkiyah berasal dari kata (คُ maksudnya suatu yang terletak dalam kekuasaannya, sebaliknya milkiy menurut istilah merupakan sesuatu ataupun benda yang secara hukum bisa dimiliki seorang untuk dimanfaatkan serta dapat dipindahkan penguasaannya kepada orang lain.

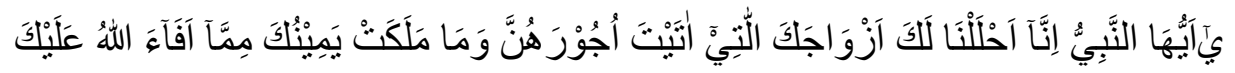

"Hai Nabi, Sesungguhnya kami telah menghalalkan bagimu istri-istrimu yang telah kamu berikan mas kawinnya dan hamba sahaya yang kamu miliki yang termasuk apa yang kamu peroleh dalam peperangan yang dikaruniakan Allah untukmu" (Q.S alAzhab [33]:50)

Tidak hanya dari penafsiran diatas, terdapat pula sebagian penafsiran kepemilikan yang dikemukakan oleh parah pakar ialah selaku berikut:

1. Muhammad Mushthafa al- Salaby mendefinisikan al- Milk sebagai pengkhususan( keistimewaan) atas sesuatu benda yang membatasi orang lain berperan atasnya serta membolehkan pemiliknya melaksanakan aksi secara langsung terhadap barang itu, sepanjang tidak terdapat halangan Syara'. 
2. Musthafa Ahmad Zarqa' mengatakan bahwa kepemilikan merupakan kekhususan( keistimewaan) yang bertabiat membatasi( orang lain) yang syara' membagikan kewenangan kepada pemiliknya melaksanakan aksi kecuali ada halangan.

3. Abdul Karim Zaidan mendefinisikan al- Milk adalah pengkhususan( keistimewaan) atas suatu barang yang membolehkan pemiliknya secara individu buat memakai ataupun melaksanakan sesuatu aksi terhadap harta tersebut tanpa terdapat suatu yang menghindari bagi syariat Islam.

Dari sebagian definisi diatas bisa dimengerti kalau kepemilikan berarti kekuasaan seorang yang didukung secara sosial untuk memegang kontrol terhadap suatu yang dipunyai secara eksklusif serta memakainya buat tujuan individu. Bersumber pada perihal tersebut, bisa dilihat kalau seorang yang memiliki hak atas sesuatu benda memiliki kebebasan terhadap benda tersebut kecuali bila terdapat hukum syara' yang menghalanginya.

Hukum syara tersebut yaitu:

1. Pemilik benda tidak cakap secara hukum semacam anak kecil, cacat mental ataupun orang yang hadapi kebangkrutan.

2. Bila benda tersebut digunakan buat kepentingan warga universal. Dalam perihal ini merupakan kepemilikan universal ataupun kepemilikan negeri.

\section{B. Kepemilikan Dari Sudut Pandang Islam}

Pemikiran Islam terhadap kepemilikan berbeda dengan kapitalisme serta sosialisme. Bagi pemikiran kapitalisme, harta tidaklah kepunyaan individu serta bukan pula kepunyaan bersama bagi sosialisme. Sebaliknya bagi pemikiran Islam harta merupakan kepunyaan Allah, sebab perihal tersebut ada dalam Al- Quran serta AsSunnah. Konsep kepemilikan dalam Islam berasal dari sudut pandang manusia yang mempunyai kemauan buat memiliki harta individu, namun pula memerlukan partisipasi pihak lain dalam kehidupan sosialnya. Harta ataupun kekayaan yang terdapat di alam semesta ini berasal dari Tuhan yang dibiarkan kepada manusia buat di manfaatkan demi kesejahteraan segala umat manusia secara ekonomi, cocok dengan kehendak Allah swt. Ia merupakan pencipta, pengatur serta pemilik seluruh suatu di alam semesta ini. Statment tersebut ada dalam Q. S Al- Maidah: 120

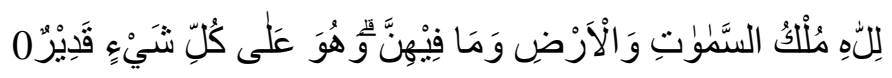

Artinya: "Milik Allah kerajaan langit dan bumi dan apa yang ada di dalamnya; dan Dia Mahakuasa atas segala sesuatu”.

Selain itu, Allah juga memberikan izin kepemilikan kepada manusia untuk menguasai harta yang telah menjadi haknya. Allah berfirman dalam Q.S An-Nuur:33

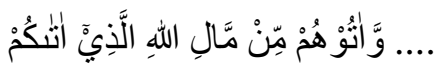


Artinya: "Berikanlah kepada mereka sebagian dari harta Allah yang dikaruniakan-Nya kepadamu....."

Kepemilikan atau hak manusia untuk memanfaatkan hartanya disebutkan dalam Q.S Al-Hadid:7

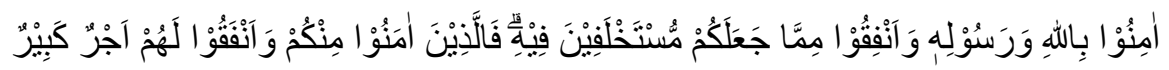

Artinya: "Berimanlah kamu kepada Allah dan Rasul-Nya dan infakkanlah (di jalan Allah) sebagian dari harta yang Dia telah menjadikan kamu sebagai penguasanya (amanah). Maka orang-orang yang beriman di antara kamu dan menginfakkan (hartanya di jalan Allah) memperoleh pahala yang besar."

Pada hakikatnya, seorang yang memiliki harta cuma menerima titipan dari Allah swt. selaku amanat buat digunakan cocok dengan kehendak pemilik- Nya. Apalagi tidak kelewatan bila dikatakan kalau pada mulanya manusialah yang berwenang memakai harta tersebut secara sepadan jadi kepunyaan individu, kepunyaan universal serta kepunyaan negeri, cocok dengan tingkatan kepentingannya tiap- tiap lewat cara- cara yang dibenarkan. Karena Allah Swt. sudah menetapkan kalau harta yang dianugerahkan- Nya ditujukan untuk memenuhi kebutuhan manusia. Sebagaimana firman Allah swt. dalam Q. S Al- Baqarah: 29

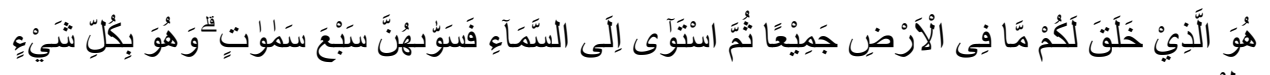

Artinya: "Dialah (Allah) yang menciptakan segala apa yang ada di bumi untukmu, kemudian Dia menuju ke langit, lalu Dia menyempurnakannya menjadi tujuh langit. Dan Dia Maha Mengetahui segala sesuatu”.

Tidak hanya itu, Islam pula menetapkan bagaimana hak kepunyaan bisa diperoleh secara legal serta adil. Oleh sebab itu, Islam sudah melarang mengambil hak kepunyaan orang lain secara paksa sebab bisa menimbulkan ketidakadilan ataupun penindasan terhadap pihak lain.

\section{Tipe Kepemilikan Dalam Islam}

Islam sudah menerangkan seluruh perihal yang berkaitan dengan mekanisme perolehan kepemilikan di tengah- tengah manusia lewat ketetapan hukum- hukumnya. Islam mengatakan terdapat tiga tipe kepemilikan, ialah kepemilikan individu, kepemilikan universal serta kepemilikan negeri.

1. Kepemilikan Pribadi

Kepemilikan individu merupakan hak kepunyaan seorang terhadapt sesuatu harta/ barang yang membagikan kewenangan terhadap seorang buat bisa memahami barang tersebut dan melarang orang lain memakainya tanpa izin dari owner. Islam memandang kepemilikan individu selaku hak orang buat menikmati seluruh ridzky dari Allah supaya bisa dipergunakan baik buat kepentingan hidup di dunia serta di akhirat. 
Buat memperoleh kepemilikan individu, sistem ekonomi Islam memerlukan tiap muslim ikut serta aktif dalam bermacam aktivitas ekonomi. Maksudnya dalam perspektif Islam, ruang lingkup bisnis sangat bermacam- macam, sebab Allah sudah menebarkan bumi serta seluruh isinya buat kemaslahatan ciptaan- Nya, sepanjang tidak berlawanan dengan syariat Islam. Allah berfirman dalam Q.S Faatir 35:12

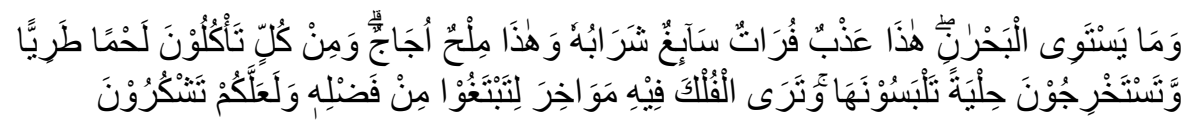

Artinya: "dan dari masing-masing laut itu kamu dapat memakan daging yang segar dan kamu dapat mengeluarkan perhiasan yang dapat kamu memakainya, dan pada masing-masingnya kamu lihat kapal-kapal berlayar membelah laut supaya kamu dapat mencari keberuntungan dan supaya kamu bersyukur."

Kepemilikan dalam Islam tidak sepenuhnya, sebab kepemilikan pada dasarnya hanya mempunyai hak untuk memakai. Oleh sebab itu, sekalipun pemilik memiliki hak eksklusif buat melarang orang lain memakai hartanya tanpa izin, masih diakui kalau Allah merupakan pemilik absolut dari seluruh harta di dunia ini.

Orang dalam sistem ekonomi Islam dikira selaku perwakilan kala warga memakai serta menggunakan harta bendanya. Perihal itu tidak hendak melenyapkan kontrol/ pembatasan. Pemikiran Islam terhadap kepemilikan individu tidak bisa dipisahkan dari ukuran guna sosial. Bila kepentingan warga menginginkan ia selaku wakil warga, hingga ia wajib mengutamakan kepentingan warga.

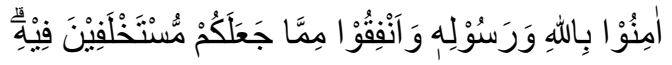

Artinya: "Berimanlah kamu kepada Allah dan Rasul-Nya dan infakkanlah (di jalan Allah) sebagian dari harta yang Dia telah menjadikan kamu sebagai penguasanya (amanah).” Q.S al-Hadid:7

\section{Kepemilikan Umum}

Kepemilikan universal merupakan hak warga untuk memakai barang/ benda yang bersidat universal ataupun dipunyai oleh orang banyak. Objek ini merupakan objek yang dinyatakan oleh al- syari selaku kepunyaan bersama warga serta tidak bisa dikendalikan oleh satu orang. Sebab ini merupakan benda publik, siapa juga bisa memakainya, namun tidak bisa memilikinya. Paling tidak terdapat 3 tipe barang yang bisa digolongkan selaku kepunyaan universal.

a. Sarana serta anjuran umum

Sarana ataupun fasilitas universal merupakan seluruh suatu yang dikira buat kepentingan universal manusia. Barang ini kepunyaan universal sebab ialah kebutuhan mendasar dari komunitas serta bisa menimbulkan perpecahan serta konflik bila tidak terpenuhi. Perihal ini dipaparkan dalam hadis Nabi saw.

"Manusia berserikat (bersama-sama memiliki) dalam tiga hal: air, padang rumput dan api" (HR Ahmad dan Abu Dawud) dalam hadis lain terdapat tambahan: "...dan harganya haram" (HR Ibn Majah dan Ibn Abbas). 
Wujud kepemilikan publik tidak terbatas pada 3 tipe itu saja, namun mencakup seluruh yang diperlukan warga. Perihal ini terjalin sebab ketetapan al- syari yang menyangka kalau barang tersebut terkategori kepunyaan universal sebab watak tertentu yang ada pada objek tersebut.

b. Benda yang tidak boleh dipahami oleh individu

Benda ini sama halnya dengan fasilitas universal semacam yang sudah di sebutkan tadinya, namun terdapat perbandingan diantara keduannya. Pembuatan kepemilikan tipe awal sama sekali tidak membatasi orang buat memilikinya, sebaliknya pembuatan kepemilikan tipe ini tidak membolehkan orang buat memilikinya. Sebagaimana sabra Rasul saw:

"Kota Mina menjadi tempat mukim siapa saja yang lebih dahulu (sampai kepadanya)"

c. Benda tambang yang jumlahnya tidak terbatas

Kepemilikan ini mencakup seluruh benda tambang yang tidak terbatas jumlahnya semacam besi, tembaga, minyak bumi, timah, dll. Tipe pertambangan ini merupakan kepunyaan publik, jadi tidak terdapat orang ataupun yang lain yang bisa mempunyai.

Demikian pula, dilarang oleh hukum buat membagikan orang ataupun organisasi hak istimewa buat mengoperasikannya, namun pihak berwenanglah yang berkewajiban buat mengelolanya. Sebaliknya, benda tambang yang kecil ataupun sangat terbatas bisa dipunyai oleh orang ataupun serikat pekerja. Perihal ini didasarkan hadits Nabi Saw. yang mengizinkan kepada Bilal ibn Harits al- Muzani mempunyai benda tambang yang telah terdapat dibagian Najd serta Tihamah. Cuma saja mereka harus membayar khumus( seperlima) dari yang diproduksinya kepada bayt al- mal.

\section{Kepemilikan Negara}

Benda kepunyaan negeri merupakan hak segala umat Islam ataupun rakyat di dalam negara, penguasaannya terletak di dasar kekuasaan negeri, serta negeri mempunyai kekuasaan buat mendonasikan ataupun mendedikasikan kepada orangorang tertentu bagi Ijtihad Islam. Yang diartikan dengan pengelolaan negeri merupakan negeri berhak mengurusnya.

Tipe kepemilikan negeri ini berbeda dengan kepemilikan universal. Bila kepemilikan umu tidak boleh dipunyai oleh orang hingga lain halnya dengan kepemilikan negeri yang boleh dipunyai orang apabila pihak pengelola ataupun negeri menghendakinya. Sebab kedudukan negeri dalam kepemilikan ini cumalah dicoba buat tujuan penerapan amanah dari warga. Negeri tidak seluruhnya memiliki hak kepunyaan tersebut.

Dalam kepemilikan negeri ini, Allah memberdayakan pemerintah buat mengendalikan urusan kalian muslimin. Oleh sebab itu, pemerintah wajib mengelola 
harta kepunyaan negeri sebaik bisa jadi buat tingkatkan pemasukan baitul maal. Ini membenarkan kalau peninggalan negeri tidak terbuang percuma serta kehabisan keuntungan.

Tujuan Islam mengendalikan seluruh tipe kepemilikan diatas merupakan buat membagikan proteksi terhadap terbentuknya 2 permasalahan mendasar berikut:

1. Harta seorang yang tidak terbatas. Sebagaimana dinyatakan dalam Q. S al- Alaq ayat 6- 7

2. Tingkat kemiskinan serta dampak negatif yang lain pada orang ataupun sosial.

\section{Pengaruh Kepemilikan dalam Islam Terhadap Pertumbuhan Ekonomi Islam}

Salah satu tujuan syariat Islam yaitu supaya warga bisa terbebas dari kemiskinan serta menempuh kehidupan yang layak ataupun sejahtera. Al- Quran serta Sunnah memerintahkan supaya tiap manusia mengelola kekayaan alam dengan metode yang produktif, menjadikannya selaku sumber pemasukan buat menunjang kebutuhan hidup mereka. Allah tidak membagikan suatu yang praktis kepada manusia dalam wujud yang lengkap serta siap gunakan, namun cuma berbentuk sarana serta sumber energi alam.

Islam mengendalikan terdapatnya hak kepunyaan ataupun kepemilikan orang serta kolektif. Perihal ini pada hakikatnya ialah wujud Islam yang sejalan dengan upaya Islam buat mengentaskan kemiskinan dengan sediakan sarana serta sumber energi alam yang siap buat pembangunan ekonomi. Oleh sebab itu, konsep kepemilikan Islam berakibat pada pertumbuhan ekonomi.

Syarat terhadap pengembangan ekonomi yang Islami hendak dipaparkan dalam pengelolaan ekonomi syariah serta berorientasi kerakyatan antara lain:

1. Ruang Lingkup Ekonomi. Dalam konsep Islam, ruang lingkup ekonomi tidak terbatas pada alibi kesejahteraan modul, namun pula mencakup hal- hal non modul yang dilarang oleh Islam buat mengonsumsi, penciptaan, serta pemasaran. Bagi Islam, konsumen serta produsen tidaklah raja, serta sikap mereka wajib dipimpin oleh kesejahteraan universal orang serta warga cocok dengan ajaran hukum Islam. Dalam sistem ekonomi Islam, anggapan dasarnya merupakan hukum syariah, yang berlaku buat orang serta kelompok warga, pengusaha, serta pemerintah.

2. Motif ekonomi Islam. Salah satu karakteristik ekonomi Islam merupakan aktivitas ekonominya yang diperuntukkan buat mencari rezeki dunia serta akhirat dalam rangka ibadah dalam makna luas selaku tugas melakukan Khalifatullah. Perihal ini sejalan dengan perintah Allah supaya manusia senang di akhirat tanpa melupakan kebahagiaan serta kesejahteraan duniawi cocok dengan yang ada dalam Q. S alQassas ayat 77

3. Prinsip dasar ekonomi Islam. Dari penafsiran serta ketentuan kepemilikan bagi perspektif Islam, bisa pula diformulasikan prinsip- prinsip dasar ekonomi Islam, antara lain.

a. Kebebasan individu. Tiap orang mempunyai kebebasan buat mengambil keputusan yang dikira butuh, sebab tanpa kebebasan orang muslim tidak bisa melaksanakan kewajibannya tercantum yang berkaitan dengan aktivitas ekonomi 
buat kesejahteraan individu serta keluarga, sepanjang tidak merugikan pihak lain.

b. Ketidaksamaan ekonomi dalam rentang yang normal. Islam mengakui terdapatnya ketidaksamaan ekonomi pada tiap orang, namun tidak membiarkannya meluas, melainkan berupaya melindungi ketimpangan ekonomi dalam kisaran yang normal.

c. Kesetaraan sosial. Islam menunjang terdapatnya kesetaraan sosial, sehingga kekayaan negeri tidak cuma dinikmati oleh kelompok warga tertentu saja. Tidak hanya itu, tiap orang wajib bekerja keras supaya tiap bisa mempunyai peluang yang sama buat melaksanakan aktivitas ekonomi.

d. Jaminan Sosial. Bagi Islam, tiap orang berhak buat hidup menemukan jaminan terpenuhi kebutuhan dasarnya.

e. Distribusi kekayaan yang luas. Sistem ekonomi Islam melarang penimbunan kekayaan pada kelompok kecil tertentu, namun wajib didistribusikan secara luas kepada mustahik. Harta yang dipunyai oleh orang yang penuhi dimensi pula ada hak orang lain didalam- Nya.

f. Larangan menimbun kekayaan. Ditujukan untuk menghindari proteksi kekayaan dicoba supaya terjalin kelangkaan benda, sehingga tingkatkan harta buat kepentingan individu pemiliknya.

g. Kesejahteraan bersama. Islam mengakui kesejahteraan orang serta kesejahteraan warga dengan silih memenuhi daripada bersaing ataupun berlawanan satu sama lain. Sistem ekonomi Islam berupaya meminimalkan mungkin konflik dengan ketentuan yang silih menguntungkan.

Dari bermacam ketentuan kepemilikan Fiqh muamalah, bisa pula dimengerti kalau Islam sediakan fasilitas untuk aktivitas ekonomi Islam, ialah:

1. Peraturan tentang harta yang halal serta yang haram

2. Larangan menimbun kekayaan

3. Perintah mendistribusikan kekayaan

4. Ketentuan zakat

5. Ketentuan Warisan

6. Pembagian harta rampasan

7. Berhemat

8. Ketentuan pajak, wakaf, infak serta shadaqah

9. Kedudukan pemerintah dalam mengendalikan serta memfasilitasi aktivitas ekonomi 


\section{KESIMPULAN}

Secara umum konsep kepemilikan berarti kekuasaan seseorang yang didukung secara sosial untuk memegang kontrol terhadap sesuatu yang dimiliki secara eksklusif dan menggunakannya untuk tujuan pribadi. Selain itu, konsep kepemilikan menurut pandangan Islam berbeda dengan pandangan kapitalisme dan sosialisme dimana menurut pandangan Islam harta adalah milik Allah, karena hal tersebut terdapat dalam Al-Quran dan As-Sunnah. Konsep kepemilikan dalam Islam berasal dari sudut pandang manusia yang memiliki keinginan untuk mempunyai harta pribadi, tetapi juga membutuhkan partisipasi pihak lain dalam kehidupan sosialnya sesuai dengan jenisnya yang terbagi menjadi tiga yaitu kepemilikan pribadi, kepemilikan umum dan kepemilikan negara. Selain itu, adanya konsep kepemilikan Islam sangat berpengaruh terhadap perkembangan ekonomi karena ketentuan pengelolaannya sudah diatur dalam Al-Quran dan As-Sunnah. 


\section{DAFTAR PUSTAKA}

Akbar, A. (2021). Konsep Kepemilikan dalam Islam. Jurnal Ushuluddin, XVIII(2), 124-140.

Rahayu, W. P. (2020). Konsep Kepemilikan Dalam Islam. Jurna; Ilmu-Ilmu Syari'ah, 7(1), 7491.

Ramli, T. A. (2005). Kepemilikan Pribadi Persfektif Islam, Kapitalis, dan Sosialis. Jurnal Sosial dan Pembangunan, 21(1), 1-13.

Sari, E. F., \& Usan. (2021). Konsep Kepemilikan Dalam Ekonomi Islam. Jurnal Ekonomi dan Bisnis Islam, 5(01), 39-54. 